\title{
Studi Komparasi Chi-Square Perilaku Konsumsi Pornografi Bagi Remaja Berdasarkan Perbedaan Jenis Kelamin
}

\section{Comparison Study Pornography Consumption Behaviour Among Adolescent Based on Sex Differences}

\author{
Puji Prihandini ${ }^{1, *}$, Putri Limilia ${ }^{2}$, Benazir Bona Pratamawaty $^{3}$
}

\author{
${ }^{1}$ Fakultas Ilmu Komunikasi, Universitas Padjadjaran Jln. Raya Bandung-Sumedang Km. 21. Jatinangor, Kab. Sumedang 45363. Jawa Barat. \\ Telepon (022) 84288888 rogram Studi, Instansi, Kota Kode Pos, Indonesia \\ *) E-mail korespondensi: puji.prihandini@unpad.ac.id
}

Diterima: 30 Juni 2020 Direvisi: 17 Agustus 2020 Disetujui: 06 Oktober 2020 Publikasi Online: 07 Oktober 2020

\begin{abstract}
The Ministry of Communication and Information throughout 2019 showed that pornographic content were the most widely complained of a total of 1,002,754 complaints. Many studies report on the behavior of pornography consumption and the results show many differences regarding the type and frequency of consumption by men and women. Teenagers are the dominant age in internet consumption in Indonesia. Thus, the study was conducted at one of the state junior high schools in Bandung. The method used in this study is quantitative method using the chi-square comparison test. The sampling technique is multistage random sampling. The results showed 99 percent of adolescents had consumed pornographic content. Differences in consumption of pornography are found in the type of media and content consumed, the source of the platform used, the type of pornographic characteristics. Whereas the frequency, place of access, and colleagues who did not consume when found no difference.
\end{abstract}

Keywords: adolescents, consumption behavior, mass media, pornography, Indonesia

\begin{abstract}
ABSTRAK
Kementrian Komunikasi dan Informasi sepanjang tahun 2019 menunjukkan bahwa konten pornografi merupakan konten yang paling banyak diadukan dengan total 1.002.754 aduan. Aduan tersebut adalah yang tertinggi dibanding jenis aduan konten internet lainya. Banyak studi melaporkan mengenai perilaku konsumsi pornografi dan hasilnya menunjukkan banyak perbedaan mengenai jenis serta frekuensi konsumsi yang dilakukan oleh laki-laki dan perempuan. Remaja merupakan usia yang dominan dalam konsumsi internet di Indonesia, sehingga penelitian dilakukan di salah satu sekolah menengah pertama negeri di kota Bandung. Metode yang digunakan adalah metode kuantitatif dengan menggunakan uji komparasi chi-square. Teknik pengambilan sampel adalah dengan multistage random sampling. Hasil penelitian menunjukkan 99 persen remaja pernah mengonsumsi konten pornografi. Perbedaan konsumsi pornorgafi ditemukan pada jenis media dan konten yang dikonsumsi, sumber platform yang digunakan, jenis karakter pornografi, sedangkan frekuensi, tempat mengkases dan rekan yang menemani saat mengonsumsi pornografi, tidak ditemukan perbedaan.
\end{abstract}

Kata kunci: Indonesia, media massa, perilaku konsumsi, pornografi, remaja

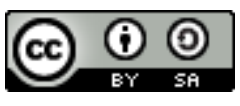

Content from this work may be used under the terms of theCreative Commons Attribution-ShareAlike 4.0 International. Any further distributionof this work must maintain attribution to the author(s) and the title of the work, journal citation and DOI.

Published under Department of Communication and Community Development Science, IPB University and in association with Forum Komunikasi Pembangunan Indonesia and Asosiasi Penerbitan Jurnal Komunikasi Indonesia.

E-ISSN: 2442-4102 | P-ISSN: 1693-3699 


\section{PENDAHULUAN}

Penggunaan media digital memiliki peran terhadap perkembangan komunikasi pembangunan. Misalnya saat ini, hampir semua institusi memanfaatkan platform media sosial sebagai sarana untuk sosialisasi program pemerintah dan penyebarluasan informasi. Pemanfaatan media sosial bukan saja menguntungkan pihak pemerintah yang memiliki kewenangan namun juga masyarakat sipil yang saat ini menjadi lebih terpapar pada informasi semenjak kehadiran media sosial. Masyarakat dapat memberikan komentar baik berupa keluhan ataupun apresiasi langsung kepada pemerintah terhadap layanan publik yang tersedia. Media menjembatani hubungan antara pemerintah dengan masyarakat untuk mempertemukan kepentingan kedua belah pihak. Masyarakat dapat menyalurkan kepentingannya secara langsung sehingga pemerintah mampu memberikan solusi secara cepat untuk mengatasi permasalahan yang terjadi tanpa melalui sistem birokrasi yang panjang. Meski masih banyak ditemui persoalan sistem birokrasi komunikasi di daerah, namun lambat laun masalah ini akan semakin berkurang seiring dengan adanya perkembangan teknologi informasi (Kusuma \& Lubis, 2016). Pemerintah Indonesia pada tahun 2006 menyatakan bahwa pembangunan, utamanya pembangunan manusia dan keluarga, tidak saja menjadi tanggung jawab dan monopoli pemerintah, tetapi memerlukan kerja sama dan partisipasi masyarakat luas (Satriani et al., 2011). Hal ini berkaitan dengan keterlibatan masyarakat dalam upaya pembangunan manusia yang secara tidak langsung berkontribusi dalam meningkatkan indeks pembangunan manusia (Human Development Index) (Satriani et al., 2011). John Naisbitt dalam bukunya Megatrends (1984) menyatakan ada sembilan kecenderungan besar yang sekarang sedang berlangsung di dunia, salah satu kecenderungan besar itu adalah beralihnya masyarakat industri ke masyarakat informasi (Pramono, 2016).

Hadirnya internet saat ini telah membuat kita menjadi masyarakat informasi. Internet mengubah pola perilaku masyarakat dalam mengonsumsi media dimana terjadi peralihan dari media arus utama ke media digital. Berdasarkan data dari APJI, penetrasi penggunaan internet di Indonesia per tahun 2017 adalah 143 juta jiwa atau kurang lebih 53\% dari penduduk Indonesia, sedangkan pengguna internet berdasarkan usia, didominasi oleh kaum remaja berusia 13-18 tahun sebanyak 75\%.

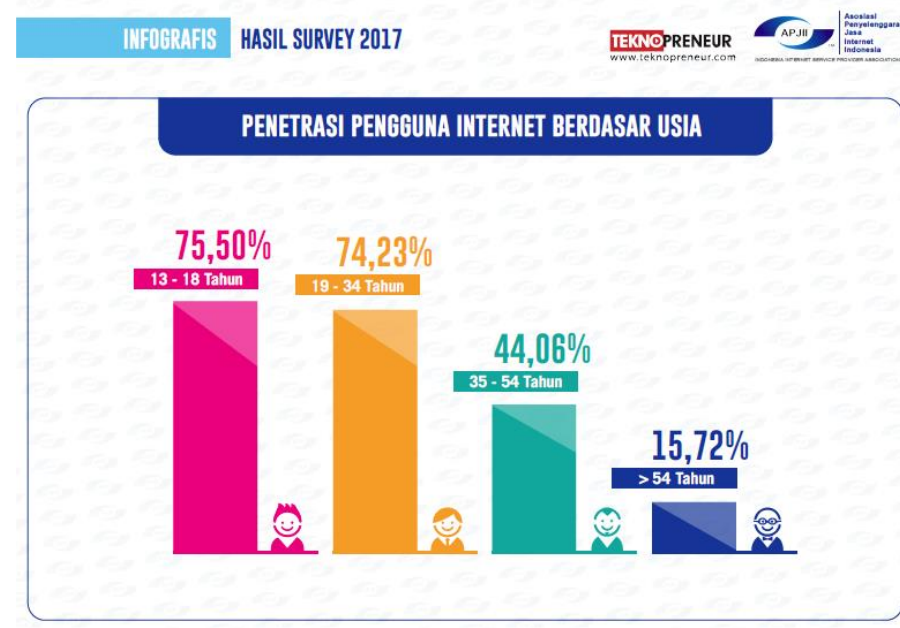

Sumber: web.kominfo.go.id

Gambar 1. Penetrasi penggunaan internet berdasarkan usia

Terkait dengan penggunaan internet bagi remaja, terdapat tiga motivasi yang sering mendorong lakilaki dan perempuan untuk menggunakan internet, yakni interaksi sosial, mengisi waktu luang dan mencari hiburan, sedangkan motivasi lain seperti pencarian informasi, relaksasi dan juga pendidikan tidak terlalu memiliki peran (Limilia \& Prihandini, 2018). Perbedaan motivasi penggunaan internet ditemukan antara gender laki-laki dan perempuan. Laki-laki sering memanfaatkan waktu luang dalam mengonsumsi internet sedangkan dalam motivasi pendidikan lebih didominasi oleh perempuan (Limilia \& Prihandini, 2018). Hasil penelitian Limilia \& Prasanti (2018) menunjukkan bahwa terdapat kesenjangan digital antara perempuan dan laki-laki. Kesenjangan tersebut terkait dengan motivasi 
(perempuan memiliki motivasi yang rendah), material (tingkat pendidikan dan pendapatan yang rendah membuat perempuan memiliki akses yang rendah ke teknologi digital), keterampilan (sebagian besar perempuan hanya sampai pada tahapan keterampilan operasional), dan penggunaan (perempuan merupakan pengguna pasif).

Keterbukaan dan kemudahan akses internet bagi remaja membuka peluang terhadap konsumsi beragam konten, termasuk pornografi. Remaja dan pornografi merupakan isu yang tidak pernah usai seiring dan sejalan dengan perkembangan teknologi komunikasi. Data KPAI (2014) melaporkan bahwa 90 persen anak-anak sudah terpapar pornografi dari usia 11 tahun (Setyawan, 2017).

Akses pornografi di Indonesia telah diatur oleh pemerintah Indonesia sebagai sebuah konten ilegal, namun akses terhadap konten tersebut masih sangat tinggi. Hal ini bisa dilihat dari data aduan konten internet sehat Kementerian Komunikasi dan Informasi tahun 2019 yang menunjukkan bahwa aduan terkait konten pornografi merupakan konten yang paling banyak diadukan dengan total 1.002.754 aduan. Aduan tersbeut adalah aduan yang tertinggi dibanding jenis aduan konten internet lainya. Angka tersebut bukan angka yang kecil, bahkan dari tahun ke tahun angka aduan terhadap konten pornografi selalu menduduki yang teratas. Hal ini disebabkan oleh kemudahan akses pornografi yang terbuka luas semenjak kehadiran akses internet dan kepemilikan ponsel pintar oleh remaja dan anakanak.

Penggunaan internet untuk konsumsi pornorgafi bagi remaja menarik perhatian peneliti, terutama mengenai bagaimana mereka mengakses, melalui media apa, frekuensi mengonsumsi pornografi, dan jenis konten pornografi yang dikonsumsi. Hasil riset sebelumnya mengenai konsumsi pornografi menunjukkan banyak sekali perbedaan perilaku konsumsi pornografi bagi laki-laki dan perempuan. Riset terkait pornografi menunjukkan konsumsi penggunaan pornografi sebagian besar didominasi oleh laki-laki. Ditemukan pada suatu penelitian, di antara beragam sampel orang dewasa yang baru muncul, $87 \%$ pria melaporkan menggunakan pornografi sampai batas tertentu dengan sekitar $20 \%$ pria melaporkan penggunaan sehari-hari atau setiap hari. Namun, hanya $31 \%$ wanita sampel yang melaporkan tingkat konsumsi pornografi, dan hanya 3,2\% yang melaporkan pola mingguan atau lebih (Carroll et al., 2008)

Penelitian lain menguatkan temuan ini ketika $75 \%$ dari 11.387 laki-laki yang berpartisipasi melaporkan mengakses atau mengunduh pornografi, sementara hanya $41 \%$ dari 3859 wanita melaporkan melakukan tindakan yang sama (Albright, 2008). Penelitian Albright (2008) menemukan bahwa laki-laki melakukan transaksi seksual secara daring 2.83 jam/minggu dimana hal ini dua kali lebih banyak dibandingkan dengan yang dilakukan oleh perempuan. Tren frekuensi ini sering terjadi dalam literatur dengan pria melaporkan penggunaan pornografi pada tingkat yang jauh lebih tinggi daripada wanita (Cooper et al., 2004).

Penelitian lain menunjukkan bahwa pria mengonsumsi pornografi secara signifikan lebih sering daripada wanita (Krejcova et al., 2018). Perbedaan gender yang signifikan dalam prevalensi konsumsi dalam 6 bulan terakhir ditemukan dihampir semua jenis pornografi yang dikonsumsi. Laki-laki ditemukan mengonsumsi seks berkelompok, aktivitas seksual wanita ke wanita, atau konten parafilik seperti fetis atau tema inses secara signifikan lebih banyak daripada wanita. Pada gilirannya, wanita ditemukan mengonsumsi foreplay seksual (Krejcova et al., 2018).

Selanjutnya ditemukan beragam sikap remaja terhadap pornografi, kebanyakan dari mereka menunjukan bahwa $76 \%$ pornografi dipandang sebagai sesuatu yang negatif dan sisanya memandang pornografi sebagai sesuatu yang menjijikan. Pandangan negatif mengenai pornografi dari responden dapat dilihat dari asosiasi yang lekat dengan pornografi seperti kecanduan, berbahaya, tidak patut, tidak bermoral dan lain-lain. Pornografi dilihat sebagai sesuatu yang menjijikan sejalan dengan penelitian yang menunjukan bahwa pornografi dinilai sebagai sesuatu yang destruktif, amoral, dan memiliki dampak negatif (Pratamawaty et al., 2020). 
Temuan pada penelitian terdahulu menyatakan bahwa pornografi merupakan aktivitas yang banyak dilakukan oleh laki-laki, namun data KPAI 2014 menunjukkan bahwa 90 persen remaja baik laki-laki dan perempuan telah mengonsumsi pornografi. Bahkan kajian budaya populer saat ini menyatakan bahwa konsumsi pornografi merupakan kegiatan yang mulai diterima bagi remaja perempuan (Brown et al., 2017). Penelitian dari Rachmaniar et al. (2018) menemukan bahwa perempuan semenjak sekolah dasar sudah memiliki ponsel yang digunakan untuk menerima dan mengirim pesan baik berupa teks dan suara. Selanjutnya setelah memasuki masa SMP, mereka beralih ke ponsel pintar yang memiliki banyak pilihan fitur. Fitur-fitur tersebut kemudian secara tidak sengaja membuat mereka dapat mengakses pornografi.

Kontradiksi ini yang menimbulkan pertanyaan bagi peneliti, bagaimana konsumsi pornografi remaja di Indonesia? Apakah konsumsi pornografi bagi remaja di Indonesia masih didominasi oleh laki-laki seperti penelitian sebelumnya? Secara kultural, Indonesia memiliki perbedaan dengan lokus dari referensi penelitian sebelumnya mengenai konsumsi pornografi yang banyak berasal dari negara Barat yang lebih liberal dan terbuka dalam seksualitas. Perbincangan mengenai seks di Indonesia masih sangat tabu, namun konsumsi pornografi sangat tinggi. Aspek lain yang menarik dan menjadi kebaruan dalam riset ini adalah belum adanya studi yang melakukan perbedaan konsumsi pornografi berdasar gender di Indonesia. Hal tersebut yang menurut peneliti menarik untuk dikaji yaitu perilaku konsumsi pornografi bagi remaja di Indonesia dewasa ini.

Penelitian ini sangat relevan dengan komunikasi pembangunan, hal ini dikarenakan pornografi sangat berkaitan dengan kesehatan publik. Hasil studi sebelumnya banyak menemukan terdapat korelasi positif antara konsumsi pornografi dengan sikap atau perilaku tertentu. Penelitian Mulya dan Hald menggunakan sampel mahasiswa di Indonesia, sebuah negara konservatif dengan mayoritas penduduk muslim dan memilik hukum anti pornografi. Penelitian ini menggunakan pengukuran PCES (Pornography Consumption Effect Scale) menunjukkan bahwa penggunaan konsumsi pornografi mempengaruhi pengetahuan seksual, sikap terhadap seks, kehidupan seks, persepsi dan sikap mereka terhadap lawan jenis. Hasil penelitian ini cukup mengejutkan dikarenakan konsumsi pornografi lebih banyak memiliki pengaruh positif dibandingkan efek negatif, hal ini berlaku bagi jenis kelamin lakilaki dan perempuan. Namun, dibandikan dengan perempuan, laki-laki dilaporkan lebih banyak memiliki efek negatif (Mulya \& Hald, 2014). Hasil penelitian ini cukup berbeda dikarenakan konsumsi pornografi memiliki efek positif bagi kedua jenis kelamin baik laki-laki dan perempuan, walaupun jika dibandingkan, pada laki-laki ditemukan efek negatif yang lebih banyak dibandingkan perempuan (Mulya \& Hald, 2014).

Hasil studi lainnya menunjukkan bahwa terdapat hubungan antara pornografi dengan fantasi seksual (Mellor \& Duff, 2019). Penelitian lain menunjukkan bahwa terdapat hubungan antara konsumsi pornografi baik bagi laki-laki maupun perempuan. Namuna apakah korelasi konsumsi pornografi dengan sikap permisif terhadap seks bagi laki-laki lebih signifikan dibandingkan perempuan? Hasil studinya menunjukkan bahwa tidak terdapat perbedaan yang signifikan, laki-laki hanya lebih berbeda signifikan 25 persen saja (yakni hanya 3 dari 12 item pertanyaan) sisanya tidak signifikan (Wright \& Vangeel, 2019). Penelitian lain menunjukkan bahwa terdapat hubungan antara konsumsi pornografi dengan sikap permisif terhadap seks, dan setelah dibandingkan antara laki-laki dan perempuan tidak terdapat perbedaan yang signifikan (Wright \& Vangeel, 2019). Hasil studi ekperimental meta analisis yang dilakukan oleh Wright et al., (2016) dengan menganalisis 22 studi dari 7 negara yang berbeda menunjukkan bahwa konsumsi pornografi memiliki hubungan dengan agresi seksual yang berlaku bagi kedua jenis kelamin. Asosiasi lebih kuat terjadi dalam bentuk verbal dibandingkan dengan agresi seksual dalam bentuk fisik, walaupun keduanya memiliki hubungan yang signifikan (Wright \& Vangeel, 2019).

Perempuan yang terinternalisasi oleh pesan-pesan yang mengandung unsur budaya populer hiperseksualitas cenderung lebih memiliki penyakit depresi, kecemasan, harga diri yang rendah, perilaku makan menyimpang (eating disorder), dan perilaku seksual yang beresiko. Lebih jauh lagi perempuan memiliki resiko kejadian pemerkosaan, dimana lingkungan yang menormalisasi pornografi. Perempuan menerima konsekuensi pornografi walaupun mereka bukan konsumen mayoritas dikarenakan mereka terlibat dalam hubungan seksual dengan laki-laki yang terbentuk oleh 
pornografi yang mengandung kekerasan yang banyak diakses secara daring. Anak laki-laki yang terekspos pornografi kekerasan secara daring merasakan trauma dari gambar-gambar yang tersedia secara daring. Penelitian menunjukkan bahwa otak remaja terpancing dengan kebaruan dan pengambilan resiko, dan industri pornografi telah membajak tahap perkembangan tersebut dengan menargetkan anak laki-laki terkespos pornografi (Dines, 2017).

Pornografi memiliki efek yang sistematis terhadap budaya dan kesehatan yang berbahaya bagi individu, keluarga, dan komunitas. Berdasarkan Fondasi CDC, kesehatan publik didefinisikan sebagai "ilmu menjaga dan meningkatkan kesehatan keluarga dan komunitas melalui promosi gaya hidup sehat" dengan memfokuskan pada peningkatan kesehatan dalam level sosial-makro (Dines, 2017). Alih-alih melihat pornografi sebagai masalah individu, pendekatan kesehatan publik melihat isu ini sebagai isu sosial yang memiliki dampak kesehatan dan budaya yang berbahaya bagi individu, keluarga, dan komunitas. Melalui pendekatan tersebut, untuk mengatasi masalah konsumsi pornografi diperlukan peran dari berbagai sektor dan multi disiplin untuk membangun kapasitas kesehatan bagi anak, keluarga, sekolah, dan komunitas. Termasuk melarang kekerasan pada perempuan dan anakanak, mengembangkan program kesehatan seksual dan pendidikan kesetaraan seks atau gender, dan memberikan edukasi kepada para tenaga kesehatan untuk membangun resistensi pada anak terhadap pornografi (Dines, 2017).

Studi mengenai kesehatan publik di Indonesia menunjukkan bahwa 50 persen sampel remaja pernah terpapar materi ponografi. Riset lain menunjukkan bahwa responden yang terpapar memiliki peluang melakukan perilaku seks pranikah 1.61 kali lebih besar dibandingkan dengan responden yang tidak terpapar pornografi (Aryati et al., 2019). Lebih jauh, temuan Aryati menunjukkan selain pornografi adanya peran sosial budaya dan orangtua dalam perilaku seks remaja sebelum menikah. Penelitian lainya pun membuktikan hal serupa. Hasil studi lain juga memperlihatkan bahwa adanya hubungan antara paparan pornografi remaja dengan perilaku penggunaan jasa WPS (Wanita Penjaja Seks) di Kabupaten Semarang (Isnaeni et al., 2017). Penelitian ini menggunakan konteks kesehatan masyarakat dimana pengujian korelasi tidak hanya memasukkan tayangan pornografi saja, tetapi juga pola asuh permisif dan konformitas teman sebaya.

Perilaku seks sebelum nikah memiliki efek jangka pendek dan panjang bagi kesehatan fisik dan mental remaja. Pada kesehatan fisik, adanya resiko tinggi terpaparnya penyakit-penyakit reproduksi seperti kanker rahim (dikarenakan hamil dan melahirkan di usia terlalu muda) dan penyakit IMS (infeksi menular seksual). Aspek kesehatan remaja ini menjadi faktor penting dalam pembangunan, dikarenakan remaja merupakan generasi penerus pembangunan.

\section{Remaja, Internet, dan Pornografi}

Menurut WHO (2018) remaja adalah penduduk dalam rentang usia 10-19 tahun, menurut Peraturan Menteri Kesehatan RI Nomor 25 tahun 2014, remaja adalah penduduk dalam rentang usia 10-18 tahun.

Sarwono (2002) menyebutkan bahwa WHO menuliskan batasan mengenai konseptual remaja. Setidaknya terdapat tiga kriteria yang digunakan WHO, yakni melihat aspek biologis, psikologis, serta sosial ekonomi. Dari aspek biologis, remaja adalah individu yang berkembang ketika pertama kali menunjukkan tanda-tanda seksual sekundernya hingga mencapai kematangan seksual. Kedua, remaja adalah individu yang mengalami perkembangan psikologis dan pola identifikasi dari anak-anak menjadi dewasa dan yang terakhir dari aspek sosial eknomi terjadi peralihan ketergantungan ekonomi yang penuh pada keadaan yang lebih mandiri dari sebelumnya (Sarwono, 2002).

Membahas mengenai pornografi, tidak mudah untuk mendefinsikan konsep tersebut. Penulis menemukan banyak perbedaaan dari para ahli dalam mendefinisikan pornografi. Pornografi tidak seperti gambar erotis tunggal. Citra dalam sebuah cerita dapat memberikan konteks untuk menilai apakah suatu produk itu memiliki muatan pornografi atau tidak. Pornografi didefinisikan sebagai produk komersial dalam bentuk drama fiksi yang dirancang untuk memperoleh atau meningkatkan gairah seksual. Hal ini mewujudkan fantasi seksual dari penonton atau penikmat yang dituju dengan menghadirkan aktivitas seksual eksplisit antara karakter yang sebagian besar bermotivasi seksual (dan pada tingkat yang lebih rendah termotivasi oleh kekuatan) yang misinya adalah untuk mengalami 
realitas erotis tanpa kendala dari realitas sehari-hari, norma sosial, dan moralitas konvensional (Informa et al., 2008).

Hasil riset juga membuktikan bahwa terdapat ragam pemahaman mengenai pornografi bagi remaja laki-laki dan perempuan (Pratamawaty et al., 2020). Bagi remaja perempuan, pornografi ditafsirkan sebagai konsumsi 18+ lalu selanjutnya disusul dengan pemahaman seksualitas dan kemudian bagian tubuh. Bagi laki-laki pornografi didominasi oleh seksualitas lalu 18+ dan kemudian disusul oleh dampak negatif (Pratamawaty et al., 2020).

Penelitian terdahulu mengenai perbedaan pola konsumsi pornografi yang dilakukan oleh pria dan wanita pernah menunjukan bahwa dibandingkan dengan wanita, pria terpapar pornografi pada usia yang lebih muda, lebih banyak mengonsumsi pornografi yang diukur berdasarkan waktu dan frekuensi, serta lebih sering menggunakan pornografi selama aktivitas seksual (Hald, 2006). Perempuan lebih sering mengonsumsi pornografi dengan pasangan seksualnya, sedangkan laki-laki lebih sering mengonsumsi sendiri atau dengan teman-temanya (Hald, 2006). Lokasi mengonsumsi pornografi bagi perempuan dan laki-laki adalah di rumah. Laki-laki dan perempuan didapati berbeda dalam preferensi mereka dalam materi-materi pornografi, laki-laki lebih menyukai pornografi yang hardcore dibandingkan dengan perempuan (Hald, 2006).

Perbedaan yang cukup besar terlihat dalam konteks personal dan interpersonal saat menyaksikan konten pornografi. Laki-laki dilaporkan menonton pornografi sendirian atau bersama teman (di luar rekan seksual) dibandingkan dengan perempuan. Sebaliknya, perempuan dilaporkan lebih seirng menyaksikan pornografi dengan rekan seksual dibandingkan dengan laki-laki (Hald, 2006). Dibandingkan dengan perempuan, data menunjukkan bahwa laki-laki mengonsumsi pornografi lebih sering saat melakukan aktivitas seksual mandiri (masturbasi), mengonsumsi pornografi saat usia lebih muda, dan menghabiskan lebih banyak waktu per minggu untuk menonton pornografi.

Penelitian lain dilakukan oleh Herbenick (2020) dalam perilaku seksual, laki-laki secara umum lebih dominan dalam menampilkan perilaku seksual dibandingkan dengan target perilaku seksual. Pornografi lebih sering diakses melalui website dengan menggunakan ponsel pintar website ataupun aplikasi, tablet, laptop dan komputer. Frekuensi mengonsumsi pornografi lebih rendah diantara perempuan dibandingkan dengan laki-laki. Laki-laki lebih banyak mengonsumsi dibandingkan dengan perempuan (Herbenick et al., 2020)

Hasil penelitian yang dilakukan oleh Paul J Wright dan Laurens Vangeel (2019) mencoba menelaah lebih jauh mengenai kaitan antara pornografi dengan sikap permisif terhadap perilaku seksual. Penelitian ini cukup menarik karena mencoba menjawab beberapa pertanyaan penelitian seperti, apakah konsumsi pornografi merupakan prediktor yang dapat diandalkan mengenai sikap permisif terhadap perilaku seks? Apakah terdapat hubungan antara konsumsi pornografi dan permisif seksual dimoderasi oleh jenis kelamin, dan jika demikian ke arah mana? Selain itu penelitian tersebut juga mencoba mempertanyakan apakah terdapat perbedaan bagi laki-laki atau perempuan yang mengonsumsi pornografi mengenai sikap permisif terhadap seks, dibandingkan dengan mereka yang tidak? (Wright \& Vangeel, 2019). Terkait dengan sikap permisif terhadap perilaku seks, pornografi sebenarnya bukan satu-satunya faktor yang mempengaruhi sikap permisif tersebut. Penelitian terdahulu memberikan alternatif bahwa usia yang lebih tua, pendidikan yang lebih rendah, religiusitas yang lebih tinggi, dan semakin konservatif idiologi politiknya diasosiasikan dengan sikap yang kurang permisif terhadap seks (Wright \& Vangeel, 2019).

Realitas lain coba dijelaskan oleh Mellor dan Duff (2019) terkait efek paparan pornografi. Mellor dan Duff melakukan penelitian lebih lanjut mengenai dampak negatif paparan pornografi dengan pelanggaran seksual. Hasil riset menunjukkan bahwa tidak ada korelasi yang konsisten antara paparan pornografi dengan perilaku pelanggaran seksual, namun studi ini menemukan bahwa penggunaan pornografi memiliki hubungan dengan fantasi seksual yang menyimpang bagi beberapa pelaku. Lebih lanjut lagi hasil riset Mellor dan Duff secara konsisten menghasilkan hasil penelitian yang cukup mengejutkan bahwa ternyata laki-laki yang lebih banyak terpapar pornografi dan tidak terlalu terpapar pornografi tidak terbukti lebih berbahaya dalam melakukan pelanggaran seksual (Mellor \& Duff, 2019). 


\section{METODE}

Penelitian ini menggunakan metode penelitian kuantitatif, dimana metode penelitian kuantitaif merupakan metode yang digunakan untuk menguji teori tertentu dengan meneliti hubungan antar variabel (Creswell, 2013). Dalam penelitian kuantitatif, peneliti memiliki asumsi-asumsi untuk menguji teori yang sifatnya deduktif. Dari hasil penerapan teori uses and gratification dan dari hasil studi literatur, peneliti berhipotesis terdapat perbedaan pola konsumsi pornografi bagi remaja siswa berjenis kelamin laki-laki dan perempuan.

Pengumpulan data pada penelitian ini menggunakan teknik pengumpulan data primer dan sekunder. Data primer didapatkan dari data hasil penyebaran kuesioner, yang terdiri pertanyaan mengenai data demografis dan data penggunaan internet dalam bentuk data nominal. Sedangkan data sekunder merupakan data hasil studi literatur mengenai isu pornografi dan remaja. Populasi dalam penelitian ini adalah siswa aktif SMP Negeri X Kota Bandung, sedangkan sampel dalam penelitian ini adalah siswa kelas 8 . Teknik pengambilan sampel yang dilakukan adalah teknik probability sampling dengan cara multistage random sampling dan hasilnya sampel dari penelitian adalah 58 siswa yang berasal dari 2 kelas siswa kelas 8 .

Peneliti menyusun kuesioner dari hasil studi literatur sebelumnya mengenai konten paparan pornografi yang pernah dilakukan oleh Wright (2019), yakni apakah siswa pernah mengonsumsi konten pornografi atau tidak (Wright \& Vangeel, 2019). Selain itu, peneliti juga menambahkan pertanyaan lain dari variabel penelitian yang dilakukan oleh Hald (2006) yakni jenis konten yang dikonsumsi, waktu terakhir kali mengonsumsi, frekuensi mengonsumsi, media yang digunakan, tempat mengakses pornografi, dan sumber akses pornografi (Hald, 2006). Semuanya terdiri dari 11 pertanyaan dan diukur dalam skala nominal. Uji validitas dalam penelitian ini telah memenuhi standar uji validitas face validity dan content validity (Crano, William D. Brewer, Marilynn B. Lac, 2015).

Teknik analisis data yang digunakan adalah teknik analisis deskriptif yakni penjabaran data hasil pengolahan kuesioner dan juga teknik analisis data statistik inferensial dengan menggunakan teknik uji chi-square.

\section{HASIL DAN PEMBAHASAN}

Penelitian dilakukan pada Janurari-Desember 2018. Pembagian kuesioner dilakukan setelah peneliti menjelaskan mengenai apa itu pornografi dan dampaknya bagi remaja, serta bagaimana cara mengurangi paparan dan konsumsi pornorgafi. Pengisian kuesioner dilakukan secara langsung/tatap muka dengan didampingi oleh tim peneliti. Jumlah perempuan lebih mendominasi dibandingkan dengan jumlah gender laki-laki dalam sampel penelitian, yaitu dengan jumlah laki-laki sebanyak 19 siswa dan perempuan 38 siswa.

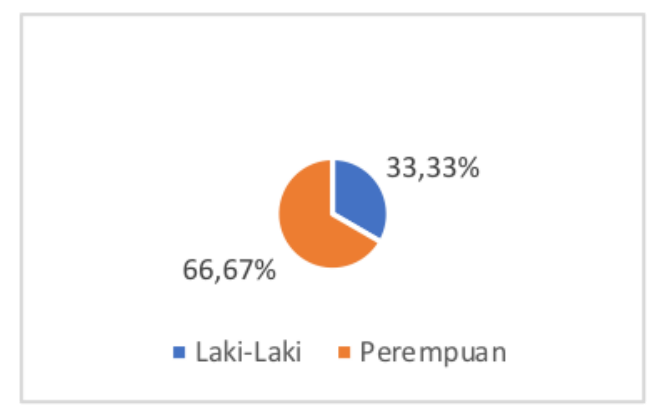

Gambar 2. Jumlah Siswa Berdasarkan Jenis Kelamin

Hasil data mengenai komposisi ataupun presentase konsumsi pornografi berdasarkan gender terlampir dalam data tabel 1 pada halaman berikutnya. Dari tabel 1, dapat dilihat data deskriptif dari hasil penelitian mengenai perilaku konsumsi pornografi oleh siswa SMP Negeri X Kota Bandung yang sudah dipisahkan berdasarkan jenis kelamin. Data tersebut terdiri dari paparan pornografi, jenis media yang digunakan, jenis konten pornografi, karakter pelaku pornografi yang dikonsumsi, sumber platform untuk mengonsumsi, tempat mengonsumsi, frekuensi mengonsumsi, hingga rekan yang menemani saat mengonsumsi pornografi. Semuanya diukur menggunakan skala nominal dengan berbagai pilihan jawaban yang tersedia. Pada variabel konsumsi pornografi, pengukuran dimulai 
dengan pertanyaan: pernahkah siswa melihat/menonton/ mengonsumsi pornografi dengan menggunakan skala nominal, alternatif jawaban ya dan tidak. Hasilnya menunjukan bahwa sebesar 95\% siswa SMP Negeri X di Kota Bandung pernah mengonsumsi konten pornografi

Tabel 1. Data Konsumsi Penggunaan Pornografi Berdasarkan gender

\begin{tabular}{|c|c|c|c|c|c|c|}
\hline No. & Variabel Konsumsi Pornografi & Jawaban & Laki-laki & $\%$ & Perempuan & $\%$ \\
\hline \multirow[t]{2}{*}{1} & \multirow{2}{*}{ Pernah Mengonsumsi Pornografi } & 1.ya & 18 & 94.74 & 36 & 94.74 \\
\hline & & 2. tidak & 1 & 5.26 & 2 & 5.26 \\
\hline \multirow[t]{7}{*}{2} & \multirow{7}{*}{$\begin{array}{l}\text { Media yang digunakan untuk } \\
\text { mengonsumsi }\end{array}$} & 1. video & 5 & 26.32 & 5 & 13.16 \\
\hline & & 2. games & 3 & 15.79 & 3 & 7.89 \\
\hline & & 3. foto & 4 & 21.05 & 9 & 23.68 \\
\hline & & 4. teks & 1 & 5.26 & 4 & 10.53 \\
\hline & & 5. film & 5 & 26.32 & 6 & 15.79 \\
\hline & & 6. majalah & & 0.00 & & 0.00 \\
\hline & & 7 lainya & 1 & 5.26 & & 0.00 \\
\hline \multirow{3}{*}{3} & \multirow{3}{*}{$\begin{array}{l}\text { Media yang menarik digunakan untuk } \\
\text { mengonsumsi }\end{array}$} & 1. video & 13 & 68.42 & 6 & 15.79 \\
\hline & & 2 teks & 3 & 15.79 & 16 & 42.11 \\
\hline & & 3. foto & 3 & 15.79 & 16 & 42.11 \\
\hline \multirow[t]{4}{*}{4} & \multirow[t]{4}{*}{ Jenis karakter yang merangsang } & $\begin{array}{l}\text { 1. karakter } \\
\text { manusia }\end{array}$ & 14 & 73.68 & 23 & 60.53 \\
\hline & & 2. karakter anime & 3 & 15.79 & 9 & 23.68 \\
\hline & & $\begin{array}{l}\text { 3. karakter } \\
\text { animasi }\end{array}$ & 1 & 5.26 & 4 & 10.53 \\
\hline & & 4. lainya & 1 & 5.26 & 2 & 5.26 \\
\hline \multirow[t]{2}{*}{5} & \multirow[t]{3}{*}{ Jenis konten pornografi yang menarik } & 1. eksplisit & 7 & 36.84 & 5 & 13.16 \\
\hline & & 2. implicit & 12 & 63.16 & 33 & 86.84 \\
\hline \multirow[t]{4}{*}{6} & & $\begin{array}{l}\text { 1. satu hari yang } \\
\text { lalu }\end{array}$ & 2 & 10.53 & 5 & 13.16 \\
\hline & \multirow[t]{3}{*}{ Terakhir kali menonton pornografi } & $\begin{array}{l}\text { 2. seminggu yang } \\
\text { lalu }\end{array}$ & 6 & 31.58 & 2 & 5.26 \\
\hline & & $\begin{array}{l}\text { 3. sebulan yang } \\
\text { lalu }\end{array}$ & 9 & 47.37 & 20 & 52.63 \\
\hline & & $\begin{array}{l}\text { 4. satu tahun yang } \\
\text { lalu }\end{array}$ & 2 & 10.53 & 11 & 28.95 \\
\hline \multirow[t]{5}{*}{7} & \multirow[t]{5}{*}{ Frekuensi pornografi } & 1. tidak pernah & 8 & 42.11 & 13 & 34.21 \\
\hline & & 2. $1-3$ kali & 11 & 57.89 & 22 & 57.89 \\
\hline & & 3. 4 - 6 kali & & 0.00 & 2 & 5.26 \\
\hline & & 4. 7-9 kali & & 0.00 & 1 & 2.63 \\
\hline & & 5.9 kali & & 0.00 & & 0.00 \\
\hline \multirow[t]{4}{*}{8} & \multirow[t]{4}{*}{ Tempat mengakses pornografi } & 1. rumah & 17 & 89.47 & 31 & 81.58 \\
\hline & & 2. warnet & 2 & 10.53 & & 0.00 \\
\hline & & 3. sekolah & & 0.00 & 3 & 7.89 \\
\hline & & 4 lain lain & & 0.00 & 4 & 10.53 \\
\hline \multirow[t]{4}{*}{9} & \multirow{4}{*}{$\begin{array}{l}\text { Media yang digunakan untuk } \\
\text { mengonsumsi pornografi }\end{array}$} & 1. handphone & 17 & 89.47 & 35 & 92.11 \\
\hline & & 2. tablet & & 0.00 & 1 & 2.63 \\
\hline & & 3 laptop & 2 & 10.53 & 2 & 5.26 \\
\hline & & 4 warnet & & 0.00 & & 0.00 \\
\hline \multirow[t]{4}{*}{10} & \multirow{4}{*}{$\begin{array}{l}\text { Sumber platform untuk mengonsumsi } \\
\text { pornografi }\end{array}$} & 1. google & 4 & 21.05 & 4 & 10.53 \\
\hline & & 2. media social & 4 & 21.05 & 26 & 68.42 \\
\hline & & 3. teman & 4 & 21.05 & 2 & 5.26 \\
\hline & & 4. website & 7 & 36.84 & 6 & 15.79 \\
\hline \multirow{3}{*}{11} & \multirow{3}{*}{$\begin{array}{l}\text { Teman yang menemani saat } \\
\text { mengonsumsi pornografi }\end{array}$} & 1. sendiri & 16 & 84.21 & 26 & 68.42 \\
\hline & & 2. pacar & & 0.00 & & 0.00 \\
\hline & & 3 teman & 3 & 15.79 & 9 & 23.68 \\
\hline
\end{tabular}


Tabel 2. Hasi Uji Chi-Aquare Test

\begin{tabular}{llll}
\hline No. & Indikator & Df & Asymp.sig (2-sided) \\
\hline 1 & Paparan Pornografi & 1 & 1,000 \\
2 & Media & 5 & 0,008 \\
3 & Konten & 6 & 0,000 \\
4 & Jenis Konten & 1 & 0,039 \\
5 & Jenis Krakter yang Merangsang & & \\
6 & Terakhir kali mneonton & 3 & 0,041 \\
7 & Frekuensi Mengonsumsi & 3 & 0,634 \\
8 & Tempat Mengonsumsi & 3 & 0,055 \\
9 & Media & 3 & 0,394 \\
10 & Sumber media & 3 & 0,008 \\
11 & Rekan saat menonton & 1 & 0,402 \\
\hline
\end{tabular}

Dalam hal paparan pornogafi, tidak ada perbedaan yang signifikan mengenai paparan pornografi antara siswa laki-laki dan perempuan. Baik keduanya pernah mengonsumsi konten pornografi. Hal ini terlihat dari data deskriptif bahwa 97 persen siswa mengaku pernah terpapar konten pornografi.

Terkait dengan jenis konten yang dikonsumsi, terdapat perbedaan jenis konten yang dikonsumsi antara siswa laki-laki dan perempuan. Data deskriptif memperlihatkan bahwa siswi perempuan lebih banyak mengakses konten pornografi dalam bentuk foto, film, dan teks sedangkan siswa laki-laki lebih banyak mengakses konten foto, video, dan games.

Dalam hal jenis konten yang dikonsumsi terdapat perbedaan signifikan antara siswa laki-laki dan perempuan. Hal ini sejalan dengan hasil survey penelitian yang menghasilkan data bahwa perempuan lebih menarik dengan konten foto dan teks dengan proporsi yang hampir seimbang, sedangkan lakilaki lebih didominasi oleh video.

Hasil uji chi-quare terkait dengan karakter pornografi yang disukai, melaporkan terdapat perbedaan signifikan antara siswa laki-laki dan perempuan dalam hal karakter pemain pornografi. Hal ini konsisten dengan data tabel deskriptif bahwa baik siswa laki-laki dan perempuan memilih karakter manusia lebih mudah membuat mereka terangsang, disusul kemudian dengan karakter anime, lalu karakter animasi.

Dalam hal jenis pornografi, terdapat perbedaan signifikan antara jenis konten pornografi yang dikonsumsi siswa laki-laki dan perempuan. Dilihat dari hasil data survey pada tabel 1, perempuan dan laki-laki mayoritas memilih jenis pornografi implisit, namun laki-laki yang memilih konten eksplisit, presentasenya lebih banyak dibandingkan perempuan.

Terlihat dari tabel 2, hasil uji stastitik pada pertanyaan terakhir kali menonton menunjukan bahwa terdapat perbedaan yang signifikan antara siswa laki-laki dan perempuan. Hal tersebut sejalan dengan perbedaan dalam masa terakhir kali menonton dimana lebih dari 50 persen perempuan mengonsumsi pornografi sebulan yang lalu, sedangkan laki-laki didominasi masa terakhir kali menonton adalah sebulan dan seminggu yang lalu.

Selanjutnya, frekuensi pornografi menunjukkan bahwa tidak ada perbedaan signifikan antara siswa perempuan dan laki-laki dalam frekuensi mengonsumsi pornografi. Berdasarkan hasil tabel 1 terlihat bahwa laki-laki dan perempuan mengonsumsi pornografi sebanyak 1-3 kali dalam seminggu, sedangkan sisanya mengaku bahwa mereka tidak pernah mengonsumsi pornografi.

Berdasarkan uji statistik memperlihatkan bahwa tidak ada perbedaan dalam jenis perangkat yang digunakan untuk mengonsumsi pornografi. Ini sesuai dengan data pada tabel 1 bahwa mayoritas lakilaki dan perempuan mengonsumsi pornografi melalui handphone. Hal ini sejalan dengan akses internet yang mereka lakukan pun didominasi dengan kepemilikan handphone.

Hasil lain melaporkan bahwa dalam tempat mengonsumsi pornografi. Data grafik yang menunjukkan bahwa baik siswa laki-laki dan perempuan mayoritas mengonsumsi konten pornografi di rumah. Hasil survey menunjukkan bahwa perempuan didominasi akses pornografi yang bersumber dari media sosial, sedangkan laki-laki lebih banyak mengonsumsi dari website online. 
Dari hasil uji statistik di atas tidak terdapat perbedaan antara siswa laki-laki dan perempuan ketika mengonsumsi pornografi. Mayoritas laki-laki dan perempuan mengonsumsinya ketika mereka sedang sendirian. Tidak ada responden yang mengonsumsi pornografi bersama pacar.

Terdapat beberapa pertanyaan yang menunjukkan perbedaan pola konsumsi pornografi antara siswa laki-laki dan perempuan, yaitu pertanyaan mengenai media yang dikonsumsi, media yang menarik untuk digunakan saat mengonsumsi pornografi, jenis konten pornografi yang dikonsumsi, karakter pemain pornografi yang membuat terangsang, waktu terakhir kali menonton, dan platform media yang digunakan. Hasil penelitian kami kurang lebih sejalan dengan penelitian sebelumnya yang juga membahas mengenai perilaku konsumsi pornografi antara laki-laki dan perempuan namun ada beberapa perbedaan dengan temuan penelitian sebelumnya. Perbedaan tersebut adalah terkait dengan jenis konten pornografi yang dikonsumsi. Laki-laki dan perempuan sama-sama memilih untuk mengonsumsi konten pornografi yang implisit, namun ditemukan lebih banyak laki-laki yang mengonsumsi kontek pornografi eksplisit dibandingkan dengan perempuan. Serupa dengan penelitian yang dilakukan oleh Hald (2006) menunjukkan terdapat perbedaan tema preferensi seksual pada lakilaki dan perempuan. Preferensi tema seksual pada laki-laki, lebih didominasi pada tema penetrasi melalui anal, seks oral, seks grup (satu laki-laki dan banyak perempuan), seks lesbian dan seks amatir. Sebaliknya, perempuan lebih cenderung menyukai pornografi yang lembut dan seks grup (satu wanita dan banyak lelaki). Perbedaan gender dalam preferensi berbagai konten pornografi juga ditemukan oleh Krejcova et al. (2018) yang menunjukkan perempuan heteroseksual lebih suka menonton film porno yang non-kekerasan dibandingkan dengan laki-laki. Penelitian kami pun kurang lebih menunjukkan bahwa laki-laki cenderung menyukai konten pornografi yang berjenis eksplisit.

Dalam konsumsi pornografi antara lelaki dan perempuan, terdapat perbedaan mengenai materi seksual yang dikonsumsi. Berdasarkan hasil penelitian Hald et al. (2015), sejumlah besar perbedaan yang signifikan ditemukan antara wanita dan pria heteroseksual baik dalam tingkat penggunaan rata-rata dari berbagai jenis pornografi dinilai dan peringkatnya relatif terhadap satu sama lain berdasarkan frekuensi yang dikonsumsi. Secara umum, pria heteroseksual ditemukan menggunakan berbagai jenis pornografi yang dinilai secara signifikan lebih dari wanita heteroseksual. Seperti dalam hasil penelitian ini, presentase laki-laki dalam mengonsumsi konten ekplisit lebih banyak dibandingkan dengan perempuan. Di antara wanita heteroseksual, tema seksual "vanila" (misalnya oral seks, vaginal seks, dan masturbasi) dan group sex (misalnya threesome, pesta pora, dan poni geng) adalah tema paling sering. Di antara pria heteroseksual, tema "vanilla", tema seks kelompok, dan tema seksual khusus wanita (contoh: payudara besar, Lolita / remaja) adalah yang paling sering digunakan.

Penemuan menarik lainya adalah jenis media yang digunakan saat mengonsumsi pornografi. Perempuan cenderung lebih menyukai mengakses konten dengan media foto dan teks, sedangkan lakilaki cenderung memilih video pornografi. Penulis menyimpulkan bahwa laki-laki lebih menyukai konten pornografi yang bersifat audiovisual yang kaya akan pesan-pesan non verbal, sedangkan perempuan lebih menyukai konten pornografi foto dan teks yang kaya akan pesan-pesan verbal. Temuan ini sejalan dengan penelitian Masroah et al. (2015) yang melaporkan bahwa jenis media yang umumnya digunakan oleh mahasiswa di FIKES Unsoed adalah film, video, gambar, majalah, dan situs porno. Film, video, dan situs porno merupakan jenis media pornografi yang paling banyak digemari oleh informan (Masroah et al., 2015).

Selain itu, perbedaan menarik untuk dibahas yakni terkait dengan jenis sumber media atau platform yang digunakan saat mengonsumsi pornografi. Laki-laki lebih memilih untuk mengaksesnya melalui website sedangkan perempuan lebih tertarik pada media sosial. Konten pornografi pada media sosial didominasi oleh konten implisit, karena konten-konten eksplisit sangat mudah untuk dilaporkan. Berbeda dengan media sosial, pada website para pengguna situs dengan lebih mudah untuk mengakses konten pornografi dnegan jenis konten eksplisit. Temuan ini sejalan dengan data sebelumnya bahwa laki-laki yang menyukai konten pornografi ekplisit jumlahnya lebih banyak dibandingkan dengan perempuan. Di samping itu hal ini juga sesuai dengan hasil studi yang ditunjukkan oleh Rachmaniar et al. (2018) bahwa siswi SMP secara tidak sengaja mendapatkan paparan pornografi salah satunya adalah dari fitur "explore" pada salah satu media social.

Di samping perbedaan, ternyata banyak pertanyaan lain yang melaporkan sebaliknya. Indikator mengenai frekuensi mengonsumsi, tempat mengonsumsi, media yang digunakan saat mengonsumsi, serta rekan yang menemani saat mengonsumsi tidak ditemukan perbedaan. Baik laki-laki dan perempuan sama-sama lebih nyaman mengonsumsi pornografi melalui media handphone dan 
dilakukan ketika sedang berada di rumah. Sama dengan literatur sebelumnya, bahwa bagi laki-laki dan perempuan, tempat utama untuk mengonsumsi pornografi adalah di rumah. Walaupun persentase perempuan lebih besar dalam mengonsumsi pornografi dalam berbagai konteks selain dirumah, dibandingkan dengan laki-laki (Hald, 2006). Dapat penulis simpulkan bahwa temuan ini selaras dengan perilaku penggunaan internet yakni menggunakan handphone dan banyak dilakukan ketika berada di rumah.

Berbeda dengan hasil riset sebelumnya yang mengklaim bahwa frekuensi menonton pornografi banyak dilakukan oleh laki-laki dibandingkan perempuan. Studi sebelumnya menyatakan bahwa pornografi merupakan aktivitas yang lebih banyak dilakukan oleh laki-laki dibandingkan perempuan (Brown et al., 2017; Hald, 2006; Herbenick et al., 2020; Krejcova et al., 2018). Sebaliknya, hasil penelitian kami melaporkan tidak ditemukan perbedaan mengenai frekuensi akses pornografi baik laki-laki dan perempuan, keduanya menyatakan pernah mengonsumsi pornografi selama 1-3 kali. Dapat disimpulkan bahwa kajian budaya populer yang menyatakan bahwa perempuan mulai menerima aktivitas mengonsumsi pornografi (Brown et al., 2017), sangat relevan dengan temuan ini. Terkait hal ini, penulis berasumsi dapat terjadi karena berkaitan dengan paparan pornografi yang dilakukan tanpa sengaja. Misalnya saja banyaknya adegan-adegan romantis dalam drama serial Korea yang menyajikan konten pornografi secara lembut, dimana perempuan remaja banyak mengonsumsi serial tersebut. Selain itu, temuan dari hasil riset yang dilakukan oleh Wright terkait sikap permisif terhadap seks menunjukkan korelasi positif antara konsumsi pornografi terhadap sikap permisif terhadap seks bagi kedua jenis kelamin (Wright \& Vangeel, 2019).

\section{KESIMPULAN}

Dari hasil penelitian di atas, beberapa item menunujukkan perbedaan mengenai pola konsumsi pornografi antara siswa laki-laki dan perempuan, yaitu item media yang dikonsumsi, media yang menarik untuk digunakan saat mengonsumsi pornografi, jenis konten pornografi yang dikonsumsi, karakter pemain pornografi yang membuat terangsang, waktu terakhir kali menonton media, dan platform media yang digunakan. Hasil penelitian kami kurang lebih sejalan dengan penelitian sebelumnya yang juga membahas mengenai perilaku konsumsi pornografi antara laki-laki dan perempuan. Indikator mengenai frekuensi mengonsumsi, tempat mengonsumsi, media yang digunakan saat mengonsumsi serta rekan yang menemani saat mengonsumsi tidak ditemukan perbedaan. Hasil penelitian ini dapat menjadi rujukan bagi para pegiat literasi media serta pemerintah, dalam menyusun kebijakan terkait dengan penggunaan handphone bagi remaja. Hal ini dikarenakan konsumsi pornografi paling banyak diakses melalui handphone. Selain itu penelitian ini bisa menjadi masukan dalam penyusunan strategi kesehatan publik bagi remaja dimana perlu banyak peran dalam memerangi pornografi. Tiap elemen memegang peranan penting, mulai dari individu, keluarga, masyarakat, komunitas, dan pemerintah.

\section{DAFTAR PUSTAKA}

Albright, J. M. (2008). Sex in America online: An exploration of sex, marital status, and sexual identity in internet sex seeking and its impacts. Journal of Sex Research.

Aryati, H., Suwarni, L., \& Ridha, A. (2019). PAPARAN PORNOGRAFI, SOSIAL BUDAYA, DAN PERAN ORANG TUA DALAM PERILAKU BERPACARAN REMAJA DI KABUPATEN SEKADAU PROVINSI KALIMANTAN BARAT. Jurnal Kesehatan Masyarakat Khatulistiwa, 127-136.

Brown, C. C., Durtschi, J. A., Carroll, J. S., \& Willoughby, B. J. (2017). Understanding and predicting classes of college students who use pornography. Computers in Human Behavior, 66, 114-121. https://doi.org/10.1016/j.chb.2016.09.008

Carroll, J. S., Padilla-Walker, L. M., Nelson, L. J., Olson, C. D., \& Barry, C., \& Madsen, S. D. (2008). Generation XXX: Pornography acceptance and use among emerging adults. Ournal of Adolescent Research.

Cooper, A., Galbreath, N., \& Becker, M. A. (2004). Sex on the internet: Further our understanding of 
men with online sexual problems. Psychology of Addictive Behaviors.

Crano, William D. Brewer, Marilynn B. Lac, A. (2015). Principles and Methods of Social Research. In Principles and Methods of Social Research. third edition. https://doi.org/10.1111/14679884.00369_4

Creswell, J. W. (2013). Research Design Pendekatan Kualitatif, Kuantitatif dan Mixed. Pustaka Pelajar.

Dines, G. (2017). Growing Up with Porn: The Developmental and Societal Impact of Pornography on Children. Dignity: A Journal on Sexual Exploitation and Violence, 2(3). https://doi.org/10.23860/dignity.2017.02.03.03

Hald, G. M. (2006). Gender Differences in Pornography Consumption among Young. Arch Sex Behav, 577-585. https://doi.org/10.1007/s10508-006-9064-0

Hald, G. M., Štulhofer, A., \& Hald, G. M. (2015). What Types of Pornography Do People Use and Do They Cluster? Assessing Types and Categories of Pornography Consumption in a Large-Scale Online Sample What Types of Pornography Do People Use and Do They Cluster? The Journal of Sex Research, 4499(October). https://doi.org/10.1080/00224499.2015.1065953

Herbenick, D., Fu, T. C., Wright, P., Paul, B., Gradus, R., Bauer, J., \& Jones, R. (2020). Diverse Sexual Behaviors and Pornography Use: Findings From a Nationally Representative Probability Survey of Americans Aged 18 to 60 Years. Journal of Sexual Medicine, 17(4), 623-633. https://doi.org/10.1016/j.jsxm.2020.01.013

Informa, R., Number, W. R., House, M., Street, M., \& Defined, P. (2008). Pornography Defined. Journal of Psychology \& Human Sexuality, September 2014, 37-41. https://doi.org/10.1300/J056v01n01

Isnaeni, N., Laksono, B., \& Deliana, S. M. (2017). Hubungan antara Pengetahuan, Pola Asuh Permisif, Tayangan Pornografi, dan Konformitas Teman Sebaya dengan Perilaku Seks Remaja yang Menggunakan Jasa WPS (Wanita Penjaja Seks) di Bandungan Kab. Semarang. Public Health Perspective Journal, 2(1).

Krejcova, L., Chovanec, M., Weiss, P., \& Klapilova, K. (2018). 314 Gender differences in pornography consumption: a representative study in the Slovak Republic. The Journal of Sexual Medicine, 15(7), S251. https://doi.org/10.1016/j.jsxm.2018.04.277

Kusuma, S., \& Lubis, D. P. (2016). Media Sosial dan Kebijakan Kapolri Mengenai "Hate Speech" (Ujaran Kebencian). Jurnal Komunikasi Pembangunan, 14(1), 151-159. https://doi.org/10.29244/jurnalkmp.14.1.

Limilia, P., \& Prasanti, D. (2018). Putri Limilia. 2(1).

Limilia, P., \& Prihandini, P. (2018). Perbedaan Motif Penggunaan Internet Antar Gender Sebagai Bentuk Baru Kesenjangan Digital. Medium, 6(2), 1-14. https://doi.org/10.25299/medium.2018.vol6(2).2003

Masroah, I. T., Gamelia, E., \& Hariyadi, B. (2015). PERILAKU SEKSUAL REMAJA AKIBAT PAPARAN MEDIA PORNOGRAFI. Kesmasindo, 7(3), 244-255. https://doi.org/10.16285/j.rsm.2010.02.010

Mellor, E., \& Duff, S. (2019). The use of pornography and the relationship between pornography exposure and sexual offending in males: A systematic review. Aggression and Violent Behavior, 46(February), 116-126. https://doi.org/10.1016/j.avb.2019.02.003

Mulya, T. W., \& Hald, G. M. (2014). Self-Perceived Effects of Pornography Consumption in a Sample of Indonesian University Students. Medi Psychology, 78-101. https://doi.org/10.1080/15213269.2013.850038

Pramono, M. F. (2016). Komunikasi Pembangunan dan Media Massa: Suatu Telaah Historis, Paradigmatik dan Prospektif. ETTISAL Journal of Communication, 1(1), 39-54. https://doi.org/10.21111/ettisal.v1i1.1053

Pratamawaty, B. B., Limilia, P., \& Prihandini, P. (2020). Young people's perception of internet 
pornography: Case of junior high school students' in West Java Indonesia. International Journal of Psychosocial Rehabilitation, 24(1), 492-501. https://doi.org/10.37200/IJPR/V24I1/PR200154

Rachmaniar, R., Prihandini, P., \& Janitra, P. A. (2018). Perilaku Penggunaan Smartphone dan Akses Pornografi di Kalangan Remaja Perempuan. Jurnal Komunikasi Global, 7(1), 1-11. https://doi.org/10.24815/jkg.v7i1.10890

Sarwono, S. W. (2002). Psikologi Remaja. Grafindo Persada.

Satriani, I., Muljono, P., \& Lumintang, R. W. . (2011). Komunikasi Partisipatif Pada Program Pos Pemberdayaan Keluarga. Jurnal Komunikasi Pembangunan, 9(2), 17-27.

Setyawan, D. (2017). KPAI: 90 Persen Anak Terpapar Pornografi Internet saat Usai 11 Tahun.

WHO. (2018). Adolescent health.

Wright, P. J., Tokunaga, R. S., \& Kraus, A. (2016). A Meta-Analysis of Pornography Consumption and Actual Acts of Sexual Aggression in General Population Studies. Journal of Communication, 66(1), 183-205. https://doi.org/10.1111/jcom.12201

Wright, P. J., \& Vangeel, L. (2019). Pornography, permissiveness, and sex differences: An evaluation of social learning and evolutionary explanations. Personality and Individual Differences, 143(January), 128-138. https://doi.org/10.1016/j.paid.2019.02.019 